\title{
PENGARUH RELIGIUSITAS TERHADAP PERILAKU MEMILIH BANK SYARIAH MELALUI KEPERCAYAAN MEREK (Studi Pada Nasabah Bank Syariah di Kota Mataram)
}

\author{
Handayani $\mathrm{R}^{1}$,Sri Darwini ${ }^{2}$, Eka Agustiani ${ }^{3}$, Imanuella ${ }^{4}$ \\ ${ }^{1}$ Fakultas Ekonomi dan Bisnis, Universitas Mataram, hrinuastuti@yahoo.com \\ ${ }^{2}$ Fakultas Ekonomi dan Bisnis, Universitas Mataram, sridarwini@unram.ac.id \\ ${ }^{3}$ Fakultas Ekonomi dan Bisnis, Universitas Mataram,ekaagustiani27@unram.ac.id \\ ${ }^{4}$ Fakultas Ekonomi dan Bisnis, Universitas Mataram, irandilolo@unram.ac.id
}

\begin{abstract}
ABSTRAK
Konstruk dan fenomena budaya telah menjadi kajian yang sangat penting dalam konsep perilaku konsumen. Selama ini belum banyak kajian yang menyertakan peranan agama sebagai unsur kebudayaan terkait perilaku konsumen, terutama dalam menggunakan religiusitas sebagai pengukurnya serta keterkaitannya dengan kepercayaan merek. Perkembangan perbankan syariah menjadi hal yang menarik untuk dikaji, terutama terkait dengan merek yang menunjukkan kekhasannya dan menggambarkan dasar kegiatan yang berbasis syariah. Penelitian ini bertujuan untuk menganalisis hubungan tingkat religiusitas individu terhadap perilaku dalam memilih bank syariah, baik secara langsung atau dimediasi oleh variabel kepercayaan merek. Penelitian dilakukan di Kota Mataram. Pengumpulan data dilakukan dengan kuesioner yang disebarkan pada 100 responden. Data diolah dengan Analisis Jalur menggunakan program SPSS. Hasil penelitian membuktikan adanya pengaruh positif dan signifikan variabel religiusitas terhadap perilaku nasabah dalam memutuskan memilih perbankan, serta kepercayaan merek terbukti memediasi pengaruh tersebut. Hasil ini memperkuat teori atau temuan empiris sebelumnya bahwa religiusitas menjadi prediktor penting bagi perilaku konsumen.
\end{abstract}

Kata Kunci: Religiusitas, Kepercayaan Merek, Keputusan Konsumen

\begin{abstract}
Religion is an invaluable factor in understanding culture as it is the most universal and influential social institution as well as it serves a significant role in attitude, values, and behaviour. There has been a lack of research that includes roles of religion as cultural element in terms of consumer behaviour especially using religiosity as its estimator. This research intents to analyze the relationship between an individual's level of religiosity towards his/her behaviour in choosing a syariah bank, and to provide deeper understanding of the relation between religiosity, brand trust, and consumer behaviour. Location for the research is Mataram City with 100 respondents. Path analysis result proves that religiosity has a significant positive influence both directly and indirectly on the respondents' decision to choose syariah banking. This finding supports the need for more understanding of religion as sub-culture, target markets and the importance of brand as company strategy in industrial positioning.
\end{abstract}

Keywords: Religiosity, Brand Trust, Consumer Behavior

\section{PENDAHULUAN}

Terdapat anggapan bahwa ada hubungan yang kompleks antara budaya dengan perilaku manusia (Schiffman \& Kanuk, 2007). Haque, Rahman \& Haque (2011) menyebutkan bahwa riset perilaku konsumen yang menitik beratkan kajian pada budaya cenderung berfokus pada nilai-nilai umum atau spesifik pada faktor-faktor subcultures seperti etnisitas dan kebangsaan sebagai pengukuran utama atas diferensiasi perilaku. Di antara kajian-kajian tersebut hanya sedikit saja yang menyertakan peranan agama sebagai unsur kebudayaan terkait perilaku konsumen. Saeed, Akhmad \& Mukhtar (2001) 
berpendapat bahwa agama merupakan faktor penting untuk mempelajari budaya karena merupakan salah satu institusi sosial yang paling universal dan berpengaruh serta memainkan peranan signifikan terhadap sikap, nilai-nilai dan perilaku baik di tingkat individu ataupun sosial. Haque, et al. (2011) dan Khraim (2010) juga beranggapan bahwa agama merupakan sebuah elemen dari budaya yang mewarnai setiap aspek dari masyarakat dan menyatu dalam kehidupan individual seseorang meskipun seseorang tergolong penganut agama tertentu atau bukan.

Pengukuran budaya bersifat sangat dinamis dalam masyarakat, namun prinsipprinsip agama membentuk pilar yang stabil dan tidak berubah dalam kurun waktu yang lama. Menurut Kim, et al. (2004) agama bukan kesenangan sesaat yang bisa berubah karena adanya perubahan tren yang dilakukan oleh pemasar, namun cenderung dalam jangka waktu lama sehingga agama dapat dipandang sebagai variabel yang bernilai dalam upaya memahami perilaku pelanggan.

Menurut Muhamad dan Mizerski (2010), komitmen agama merupakan salah satu faktor penting yang mempengaruhi konsumen di pasar, yang menunjukkan sejauh mana satu orang menganut nilai-nilai yang stabil dan pragmatis yang tidak sering kali berubah (Khraim, 2010, yang sering disitilahkan sebagai religiusitas. Komitmen keagamaan bervariasi dari individu satu dengan individu lainnya. Sementara, orang-orang religius sangat mengikuti prinsip-prinsip agama mereka seperti teratur melaksanakan ibadah, berkomitmen kuat pada ajaran agama dan asosiasi kelompok, sebaliknya individu yang memiliki kepercayaan dan prinsip agama lemah merasa bebas untuk berperilaku dengan cara lain (Mokhlis \& Spartks 2007). Dengan demikian, perbedaan derajat kepatuhan individu untuk berkomitmen pada agama secara langsung berdampak pada perilaku pilihan di pasar dan kewajiban untuk merek tertentu (Khraim, 2010;. Rindfleisch et al, 2005). Hal ini menjadikan penelitian religiusitas menjadi hal yang penting untuk dilakukan terutama dalam meneliti hubungan agama dengan perilaku konsumen. (Borzooei \& Asgari, 2014).

Nilai-nilai agama yang kuat dalam diri individu apabila juga dipresentasikan dalam produk atau jasa yang ditawarkan oleh perusahaan atau organisasi akan menimbulkan kesan sesuai antara individu tersebut dengan produk atau jasa yang ditawarkan. Kesan sesuai tersebut dapat menjadi landasan bagi munculnya keyakinan individu terhadap suatu produk atau jasa yang ditawarkan. Keyakinan pelanggan atas kualitas dan kehandalan merek yang ditawarkan serta serta dilihat dari berbagai atribut yang melekat pada suatu merek seperti atribut nilai agama merupakan perwujudan adanya kepercayaan merek. Kepercayaan pada merek merupakan kemauan pelanggan untuk mempercayai merek dengan segala resikonya dan menjadi faktor penentu dalam penguatan perilaku pembelian (Lau \& Lee, 1999).

Berdasarkan hasil beberapa penelitian terdahulu terkait pengaruh religiusitas terhadap perilaku konsumen dalam memilih jasa perbankan di Indonesia memberikan hasil yang beragam. Lestari (2015), Santosa, Sinarasri (2013) menemukan pengaruh signifikan pada hubungan kedua variabel tersebut, namun Abhimantara, Maulina, Aguastianingsih (2013), Rifai, et al. (2013) menunjukkan hasil berbeda, meskipun responden menyadari adanya konsep bank konvensional yang bertentangan dengan ajaran agama Islam, namun hal tersebut memilik pengaruh yang tidak signifikan pada keputusan mereka dalam memilih jasa perbankan. Perbedaan hasil penelitian tersebut menjadi research gap yang menjadi dasar penelitian selanjutnya. Penelusuran lebih jauh menunjukkan perlunya pembuktian bahwa kepercayaan merek sebagai variabel yang memediasi pengaruh religiusitas terhadap perilaku konsumen, sehingga dirasa perlu untuk mengakaji hubungan 
kausal antara religiusitas, dengan kepercayaan merek dan perilaku pembelian terutama dalam usaha jasa perbankan Syariah.

Fenomena nilai Islami dan komitmen umat (religiusitas) dalam kajian pemasaran sebagai sebuah disiplin baru telah menarik perhatian baik dari pihak akademisi maupun praktisi. Wilson \& Liu (2011) menyimpulkan bahwa perilaku konsumen Muslim merupakan komunitas budaya yang besar sehingga menjadi sebuah kebutuhan bagi pemasar untuk memahaminya. Komunitas Islam, yang merupakan bagian dari konsumen; hidup dalam serangkaian prinsip-pinsip atas keyakinan dan nilai-nilai kebenaran (Sarwar, 1989). Seorang muslim dituntut untuk dapat merefleksikan ajaran-ajaran Islam dalam kesehariannya. Atmosfer Islami sebenarnya sangat identik dengan kehidupan masyarakat di indonesia pada umumnya karena Islam merupakan agama mayoritas. Demikian pula dengan masyarakat pulau Lombok sebagai pulau seribu Masjid. Oleh karena itu penelitian ini di fokuskan pada masyarakat muslim kota Mataram yang diasumsikan memiliki permasalahan yang lebih kompleks dan cenderung berada dalam perkembangan lingkungan yang heterogen.

Perumusan Masalah:

Berdasarkan uraian pada latar belang tersebut, maka perumusan dalam penelitian ini adalah sebagai berikut:

1. Apakah religiusitas berpengaruh terhadap perilaku konsumen dalam memilih bank syariah,

2. Apakah kepercayaan merek memediasi pengaruh religiusitas terhadap perilaku konsumen dalam memilih bank syariah.

Berdasarkan perumusan masalah tersebut, maka penelitian ini bertujuan untuk :

1. Mengidentifikasi dan menjelaskan pengaruh religiusitas terhadap perilaku konsumen dalam memilih perbankan syariah.

2. Mengidentifikasi dan menjelaskan peran mediasi kepercayaan merek terhadap hubungan antara religiusitas dan perilaku konsumen dalam memilih perbankan syariah

\section{TINJAUAN LITERATUR}

\section{Religiusitas}

Religiusitas didefinisikan sebagai sejauh yang mana seorang individu berkomitmen untuk agama yang dianutnya, seperti sikap dan perilaku individu mencerminkan komitmen ini (Sungkar, 2010). Suka atau tidak suka konsumen sangat dipengaruhi oleh bagaimana komitmen mereka terhadap ajaran agama. Konsumen akan mempertimbangkan membeli produk baru jika produk tidak melanggar atau bertentangan dengan ajaran agama yang dianut (Zucker, 1986). Komitmen keagamaan mempengaruhi orientasi konsumen mengenai pola konsumsi, serta perilaku sosial mereka. Anggapan bahwa orang yang sangat religius akan mengevaluasi dunia melalui skema agama dan mengintegrasikan/agamanya ke dalam / hidupnya (Mokhlis, 2006). Komitmen beragama memainkan peran penting dalam kehidupan masyarakat yang membentuk keyakinan, pengetahuan, dan sikap, terlepas dari orientasi keagamaan mereka (Muslim, Kristen, Budha, dan lain-lain), dan mempengaruhi perasaan dan sikap masyarakat terhadap konsumsi (Jamal, 2003).

Religiusitas merupakan bentuk aspek religi yang telah dihayati oleh individu di dalam hati. Makna religiusitas digambarkan dalam beberapa aspek-aspek yang harus dipenuhi sebagai petunjuk mengenai bagaimana cara menjalankan hidup dengan benar 
agar manusia dapat mencapai kebahagiaan, baik di dunia dan ahirat. Religiusitas diwujudkan dalam berbagai sisi kehidupan termasuk aspek ekonomi. Pada zaman modern ini kegiatan perekonomian tidak akan sempurna tanpa adanya lembaga perbankan. Lembaga perbankan tersebut termasuk ke dalam aspek syariat yang berhubungan dengan kegiatan muamalah. Dalam kegiatan bermuamalah, perlu diperhatikan bahwa semua transaksi dibolehkan kecuali yang diharamkan oleh syariat, dan penyebab terlarangnya sebuah transaksi menurut syariat dikarenakan adanya faktor haram zatnya, haram selain zatnya, dan tidak sah.

\section{Kepercayaan Merek}

Merek yang kuat dalam persaingan pasar merupakan tujuan utama dari banyak organisasi karena memungkinkan terciptanya keuntungan bagi perusahaan, termasuk berkurangnya resiko, keuntungan yang lebih besar, kerjasama dengan pihak lain yang dapat meningkatkan serta adanya keperluan untuk melakukan brand extension. Dengan demikian pertanyaan yang muncul adfalah hal-hal apa saja yang dapat menimbulkan kekuatan merek.

Menurut Gurviez dan Korchia (2003) dalam Aulia Damayanti (2010) dari sudut pandang konsumen kepercayaan merek merupakan variabel psikologis yang mencerminkan sejumlah akumulasi asumsi awal yang melibatkan kredibilitas, integritas, dan benevolence, yang dilekatkan pada merek tetentu. Menurut Lau dan Lee dalam Tjiptono (2007). Kepercayaan pada merek (trust in a brand) sebagai kesediaan atau kemauan konsumen untuk mempercayai atau mengandalkan merek dalam situasi (segala resikonya) karena ada harapan bahwa merek bersangkutan akan memberikan hasil positif bagi konsumen,

Menurut Delgado (2004) dalam Erna Ferrinadewi (2008) kepercayaan merek adalah harapan akan kehandalan dan intense baik merek. Berdasarkan definisi ini kepercayaan merek mereflesikan dua komponen penting yakni brand reliability dan brand intentions. Brand reliability atau kehandalan merek yang bersumber pada keyakinan konsumen bahwa produk tersebut mampu memenuhi nilai yang dijanjikan atau dengan kata lain persepsi bahwa merek tersebut mampu memenuhi kebutuhan dan kepuasan konsumen. Brand reliability merupakan hal essensial bagi terciptanya kepercayaan terhadap merek karena kemampuan merek memenuhi nilai yang dijanjikan akan membuat konsumen menaruh rasa yakin akan kepuasan dimasa depan. Sedangkan brand intention didasarkan pada keyakinan konsumen bahwa merek tersebut mampu mengutamakan kepentingan konsumen ketika masalah dalam konsumsi produk muncul secara tidak terduga. Erna Ferrinadewi (2008).

\section{Perilaku Konsumen}

Untuk sukses perusahaan harus menentukan kebutuhan dan keinginan berbagai target pasar tertentu dan memberikan kepuasan yang diinginkan lebih baik dari pesaing. Pemasar harus membuat apa yang dapat dijualnya, daripada berusaha menjual apa yang telah dibuatnya, dengan demikian konsep pemasaran berfokus pada kebutuhan pelanggan (Schiffman \& Kanuk, 2007). Oleh karena itu kunci untuk mencapai tujuan organisasi adalah bagaimana menentukan kebutuhan dan keinginan pasar sasaran dan memberikan kepuasan yang diinginkan secara lebih efektif dan efisien daripada pesaing, melindungi atau meningkatkan pelanggan serta kesejahteraan masyarakat (Kotler, 2003). 
Dalam upaya memahami bagaimana manusia (konsumen) memenuhi kebutuhan dan keinginannya, sehingga perusahaan mampu memberikan produk dan berbagai kegiatan pemasaran lainnya secara lebih efisien dan efektif, pemahaman terkait dengan perilaku konsumen menjadi hal yang sangat penting bagi pemasar. Apa yang dibutuhkan konsumen, mengapa mereka membutuhkan suatu produk, bagaimana mereka mendapatkan produk, apa saja yang mempengaruhi mereka dalam membeli produk, bagaimana mereka mengkonsumsi dan mengevaluasi produk, menjadi hal yang perlu dipahami oleh perusahaan. Pengetahuan yang cukup tentang perilaku konsumen dapat memberikan pedoman bagi perusahaan, organisasi non profit, dan pembuat kebijakan dalam menentukan dan melakukan kegiatan pemasaran/ strategi pemasarannya (Hawkins et al., 2004).

Perilaku konsumen merupakan hal-hal yang mendasari konsumen untuk membuat keputusan pembelian. Studi perilaku konsumen terpusat pada cara individu mengambil keputusan untuk memanfaatkan sumber daya mereka yang tersedia (waktu, uang, usaha) guna membeli barang-barang yang berhubungan dengan konsumsi, yang mencakup "apa yang mereka beli, mengapa mereka membeli, di mana mereka membeli, dan seberapa sering mereka menggunakannya" (Schiffman \& Kanuk, 2007).

\section{Pengembangan Hipotesis}

Berbagai kajian menyimpulkan bahwa agama merupakan komponen dasar dari budaya dan berhubungan dengan banyak aspek kehidupan konsumen dan perilaku (Haque, rahman \& Haque, 2011; Arham, 2010; Khraim, 2010; Mokhlis, 2009; Mokhlis, 2007). Lebih lanjut Haque, Rahman \& Haque (2011) menegaskan bahwa niat beli dari konsumen merupakan bias persepsi konsumen yang bisa jadi muncul dari dorongan emosional yang muncul dari fanatisme agama. Hasil penelitian Lestari (2015), menunjukkan hasil adanya pengaruh antara religiusitas terhadap preferensi mahasisa universitas Brawijaya untuk menabung pada bank Syariah. Rivai et al. (2013), menemukan hal yang konsisten dan melakukan penelitian pada masyarakat di Sumatera Barat. Berdasarkan hasil beberapa penelitian tersebut dapat diajukan hipotesis :

H1. Terdapat pengaruh religiusitas terhadap perilaku konsumen dalam memilih bank syariah di kota Mataram

Persepsi pelanggan atas kualitas merek tercipta berdasarkan isyarat informasional yang diasosiasikan dengan merek tersebut (Schiffman \& Kanuk, 2007). Isyarat tersebut bersifat intrinsik atau ekstrinsik dan keduanya atau salah satunya bisa terdapat pada merek yang menjadi dasar bagi persepsi atas kualitas. Pelanggan cenderung mempercayai bahwa mereka mendasari evaluasi atas isyarat intrinsik karena meungkinkan pelanggan untuk membuat keputusan basik yang positif ataupun negatif sebagai pilihan produk yang rasional dan obyektif. Pelanggan seringkali mengukur kualitas dan dasar isyarat yang ditampilkan secara eksternal pada produk itu sendiri seperti harga, citra merek, citra perusahaan, citra toko, atau bahkan citra negara asal. Khraim (2010) meniliti variabel culture dan sub-culture menitik beratkan unsurunsur agama, karena agama memainkan peranan penting dalam mempengaruhi perilaku sosial dan perilaku pelanggan. Hasil penelitiannya mengindikasikan semakin tinggi tingkat religiusitas individu, akan meningkatkan kepercayaa pada produk berbasis nilai agama dan mempengaruhi mereka dalam memutuskan membeli produk. Dari uraian tersebut maka dapat dirumuskan hipotesis sebagai berikut : 


\section{H2. Kepercayaan merek sebagai mediasi hubungan antara religiusitas dengan perilaku konsumen dalam memilih bank syariah di kota Mataram}

\section{METODE PENELITIAN}

Sasaran dalam penelitian ini pada pengembangan ilmu, maka jenis penelitian ini merupakan penelitian dasar (Ferdinand, 2011). Berdasarkan jenis riset termasuk riset kausal, karena ingin mencari penjelasan dalam bentuk hubungan sebab akibat antara beberapa konsep atau beberapa variabel yang dikembangkan dalam manajemen (Ferdinand, 2011). Data dikumpulkan melalui kuesioner, yang diberikan secara langsung kepada nasabah bank syariah di Mataram. Populasi dalam penelitian ini adalah seluruh nasabah muslim/muslimah bank syariah di kota Mataram. Berdasarkan pertimbangan luasnya wilayah, dan banyaknya jumlah nasabah, maka teknik sampling yang digunakan adalah purposive sampling, dan fokus pada kawasan bank syariah di kota Mataram. Jumlah responden dalam penelitian ini ditentukan secara purposive sampling sebanyak 100 orang dengan pertimbangan jumlah populasi belum diketahui secara pasti, dengan kriteria: usia diatas 17 tahun, dan berasal dari Kota Mataram.

Sebelum item-item ini digunakan dalam kuesioner, dilakukan pengujian Validitas dan Reliabilitas. Berdasarkan hasil output SPSS menunjukkan bahwa corelation product moment pada seluruh item yang digunakan untuk mengukur seluruh variabel menunjukkan nilai korelasi lebih besar dari 0,3. Demikian pula angka cronbach alpha lebih besar dari angka minimum yang disyaratkan yakni sebesar 0,6 . Dengan demikian seluruh item atau instrumen penelitian tersebut valid dan reliabel. Untuk memberikan gambaran awal atau kecenderungan dari data secara umum, serta mempermudah penafsiran dan penjelasan dilakukan analisis Diskriptif. Sedangkan dalam pembuktian hipotesis yang diajukan digunakan adalah Analisis Jalur (Path Analysis).

\section{HASIL PENELITIAN DAN PEMBAHASAN}

Data yang dikumpulkan dari 100 orang responden menunjukkan $64 \%$ berjenis kelamin laki laki, dengan usia dominan (41\%) berada pada rentang 25 - 35 tahun. Sebanyak $42 \%$ responden menjadi PNS/ anggota POLRI dengan pendidikan terakhir pada tingkat Strata satu (sarjana), yakni sebanyak $45 \%$, dengan jumlah pendapatan per bulan terbanyak (27\%) berkisar antara Rp 3 juta sampai Rp. 4 juta. Sebagian besar responden (77\%) menjadi nasabah antara 1 sampai 3 tahun serta $64 \%$ dari responden menjadi nasabah bank umum atau bank konvensional lainnya. berikut :

Berdasarkan hasil analisis Deskriptif jawaban responden, diperoleh data sebagai

Tabel: Distribusi Tanggapan Responden Terhadap Variabel Penelitian

\begin{tabular}{|l|l|c|}
\hline VARIABEL & \multicolumn{1}{|c|}{ ITEM } & $\begin{array}{c}\text { RATA- } \\
\text { RATA }\end{array}$ \\
\hline Religiusitas & $\begin{array}{l}\text { Saya sering membaca buku-buku dan majalah tentang } \\
\text { agama Islam }\end{array}$ & 3,85 \\
& $\begin{array}{l}\text { Saya berkontribusi dalam hal keuangan untuk } \\
\text { organisasi/kegiatan keagamaan Islam }\end{array}$ & 3,50 \\
& $\begin{array}{l}\text { Saya selalu mengisi waktu saya untuk meningkatkan } \\
\text { pemahaman saya terhadap agama Islam } \\
\text { Agama Islam sangat penting bagi saya karena } \\
\text { menjawab banyak pertanyaan tentang makna }\end{array}$ & 4,21 \\
\hline \multicolumn{1}{|c|}{4,54} \\
\hline
\end{tabular}

$52 \mid$ Pengaruh Religiusitas Terhadap Perilaku Memilih Bank Syariah... 


\begin{tabular}{|c|c|c|}
\hline VARIABEL & ITEM & $\begin{array}{l}\text { RATA- } \\
\text { RATA }\end{array}$ \\
\hline & $\begin{array}{l}\text { kehidupan } \\
\text { - } \text { Keyakinan agama saya (Agama Islam) ada di balik } \\
\text { seluruh cara saya untuk hidup. } \\
\text { - } \quad \text { Keyakinan agama mempengaruhi semua urusan saya } \\
\text { dalam hidup. } \\
\text { - } \\
\text { Penting bagi saya menghabiskan waktu untuk } \\
\text { memikirkan hal-hal yang bersifat keagamaan sebagai } \\
\text { refleksi pribadi. } \\
\text { - } \quad \text { Saya menikmati bekerja dalam kegiatan agama saya }\end{array}$ & $\begin{array}{l}3,96 \\
4,06 \\
4,16 \\
3,85\end{array}$ \\
\hline & & 4,02 \\
\hline \multirow[t]{2}{*}{$\begin{array}{l}\text { Kepercayaan } \\
\text { Merek }\end{array}$} & $\begin{array}{l}\text { - Saya percaya bahwa bank Syariah dalam kegiatannya } \\
\text { sesuai dengan nilai agama Islam } \\
\text { - Percaya bahwa Bank Syariah dapat memenuhi } \\
\text { harapan nasabah sesuai ajaran Islam } \\
\text { - Percaya bahwa Bank Syariah mengutamakan } \\
\text { kepentingan nasabah } \\
\text { - Bank Syariah selalu menyelaraskan produk yang } \\
\text { ditawarkan dengan kebutuhan nasabah }\end{array}$ & $\begin{array}{l}3,46 \\
3,64 \\
3,81 \\
3,78\end{array}$ \\
\hline & & 3,68 \\
\hline \multirow[t]{2}{*}{$\begin{array}{l}\text { Perilaku } \\
\text { Memilih } \\
\text { Nasabah }\end{array}$} & $\begin{array}{l}\text { - Bank Syariah merupakan prioritas utama (pilihan } \\
\text { utama) dalam menggunakan jasa perbankan. } \\
\text { - Bersedia mengikuti dan mendukung segala kebijakan } \\
\text { bank syariah } \\
\text { - Bersedia untuk merekomendasikan/ meyakinkan } \\
\text { pihak lain mengenai hal positif dari bank syariah }\end{array}$ & $\begin{array}{l}3,45 \\
3,63 \\
3,67 \\
\end{array}$ \\
\hline & & 3,58 \\
\hline
\end{tabular}

Pengujian Hipotesis

Pembuktian hipotesis yang diajukan dalam penelitian ini dilakukan dengan analisis jalur (Path Analysis), yang menguji pengaruh langsung variabel Religiusitas (X) terhadap variabel Perilaku memilih nasabah (Y), dan pengaruh variabel Religiusitas (X) terhadap Perilaku memilih Nasabah (Y) melalui Kepercayaan Merek (Z). Oleh karena itu hubungan struktural dengan analisis Jalur terkait pembuktian pengaruh tersebut dapat dirumuskan sebagai berikut :

$$
\begin{aligned}
& Z=\rho Z X+C_{2} \quad \ldots \ldots \ldots \ldots . . M \text { Model 1 } \\
& Y=\rho Y X+\rho Y Z+C_{3} \ldots \ldots \ldots \ldots .
\end{aligned}
$$

Adapun kerangka konseptual dari model analisis jalur variabel yang diteliti tersebut digambarkan sebagai berikut

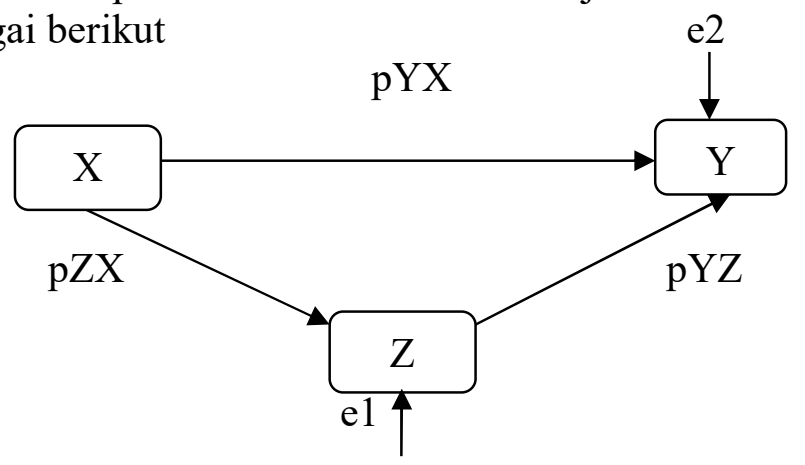

Pengaruh Religiusitas Terhadap Perilaku Memilih Bank Syariah... 53 
Pengolahan data dengan SPSS untuk Model 1 dan Model 2, menunjukkan hasil sebagai berikut

Model Summary

\begin{tabular}{|c|c|r|r|r|}
\hline $\begin{array}{l}\text { Mode } \\
1\end{array}$ & $\mathrm{R}$ & R Square & $\begin{array}{c}\text { Adjusted } \\
\text { R Square }\end{array}$ & $\begin{array}{c}\text { Std. Error } \\
\text { of the } \\
\text { Estimate }\end{array}$ \\
\hline 1 &, $682(\mathrm{a})$ &, 466 &, 460 &, 41248 \\
\hline 2 &, $816(\mathrm{~b})$ &, 666 &, 659 &, 41648 \\
\hline
\end{tabular}

a Predictors: (Constant), $\mathrm{X}$

b Predictors: (Constant), Z, X

Output SPSS tersebut menunjukkan Model 1; Religiusitas berpengaruh positif dan siginifikan terhadap kepercayaan merek. Besaran pengaruh adalah 0,466 atau 46,6\% yang merupakan kontribusi dari variabel religiusitas terhadap kepercayaan merek. Sedangkan 53,4 \% dipengaruhi variabel lain diluar model. Model 2; menunjukkan Religiusitas (X) dan Kepercayaan merek (Z) berpengaruh positif dan siginifikan terhadap keputusan memilih nasabah (Y). Besaran pengaruh adalah 0,666 atau 66,6\% yang merupakan kontribusi dari variabel religiusitas dan kepercayaan merek terhadap perilaku keputusan memilih perbankan syariah. Sedangkan 33,4\% dipengaruhi variabel lain diluar model. Kedua Model terjadi secara signifikan. Hal ini dapat dilihat dari probability (sig) atau < 0,05., yang ditunjukkan pada Tabel berikut :

ANOVA(b)

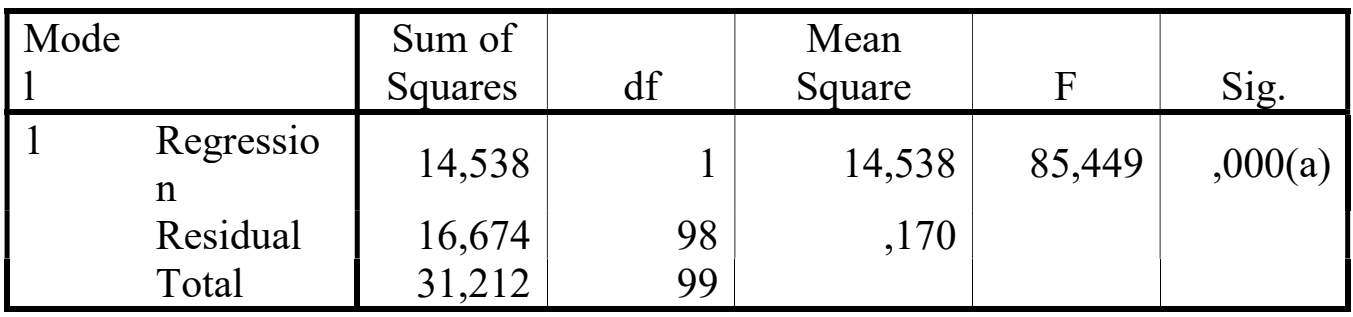

a Predictors: (Constant), $\mathrm{X}$

b Dependent Variable: $\mathrm{Z}$

ANOVA(b)

\begin{tabular}{|ll|r|r|r|r|l|}
\hline $\begin{array}{l}\text { Mode } \\
1\end{array}$ & $\begin{array}{r}\text { Sum of } \\
\text { Squares }\end{array}$ & df & \multicolumn{1}{c|}{$\begin{array}{c}\text { Mean } \\
\text { Square }\end{array}$} & \multicolumn{1}{c|}{ F } & Sig. \\
\hline 2 & Regressio & 33,481 & 2 & 16,740 & 96,511 &, $000(\mathrm{a})$ \\
& $\mathrm{n}$ & & & & \\
& Residual & 16,825 & 97 &, 173 & & \\
& Total & 50,306 & 99 & & & \\
\hline
\end{tabular}

54 | Pengaruh Religiusitas Terhadap Perilaku Memilih Bank Syariah... 
a Predictors: (Constant), Z, X

b Dependent Variable: Y

Besarnya koefisien masing-masing variabel bebas ditunjukkan pada tabel berikut :

Coefficients(a)

\begin{tabular}{|c|c|c|c|c|c|c|}
\hline \multirow[b]{2}{*}{$\begin{array}{l}\text { Mode } \\
1\end{array}$} & & \multicolumn{2}{|c|}{$\begin{array}{c}\text { Unstandardized } \\
\text { Coefficients }\end{array}$} & \multirow{2}{*}{$\begin{array}{c}\text { Standardized } \\
\text { Coefficients } \\
\text { Beta } \\
\end{array}$} & \multirow{2}{*}{$\mathrm{t}$} & \multirow{2}{*}{$\begin{array}{l}\text { Sig. } \\
\text { Std. } \\
\text { Error }\end{array}$} \\
\hline & & B & $\begin{array}{l}\text { Std. } \\
\text { Error }\end{array}$ & & & \\
\hline 1 & (Constant & 1,041 & ,288 & & 3,619 &, 000 \\
\hline & $\mathrm{X}$ & ,655 &, 071 &, 682 & 9,244 &, 000 \\
\hline
\end{tabular}

a Dependent Variable: $\mathrm{Z}$

\section{Coefficients(a)}

\begin{tabular}{|c|c|c|c|c|c|c|}
\hline \multirow[b]{2}{*}{$\begin{array}{l}\text { Mode } \\
1\end{array}$} & & \multicolumn{2}{|c|}{$\begin{array}{l}\text { Unstandardized } \\
\text { Coefficients }\end{array}$} & \multirow{2}{*}{$\begin{array}{c}\text { Standardized } \\
\text { Coefficients } \\
\text { Beta } \\
\end{array}$} & \multirow{2}{*}{$\mathrm{t}$} & \multirow{2}{*}{$\begin{array}{l}\text { Sig. } \\
\text { Std. } \\
\text { Error }\end{array}$} \\
\hline & & B & $\begin{array}{l}\text { Std. } \\
\text { Error }\end{array}$ & & & \\
\hline 1 & (Constant &,- 666 & 309 & & $-2,155$ & ,034 \\
\hline & X & ,538 & ,098 & ,442 & 5,498 &, 000 \\
\hline & Z &, 568 &, 102 & 448 & 5,573 & 000 \\
\hline
\end{tabular}

a Dependent Variable: Y

Berdasarkan ouput tersebut, pengaruh kausal empiris pada kedua Model digambarkan pada persamaan berikut :

$$
\begin{aligned}
& Z=\rho Z X+\rho Z \epsilon_{1}, \ldots \ldots \ldots \ldots \ldots . . . \text { Model } \\
& Z=0,682 X+0,731 \epsilon_{1} \\
& Y=\rho Y X+\rho Y Z+C_{2} \ldots \ldots \ldots . . \text { Model } 2 \\
& Y=0,442 X+0,448 Z+0,578 \epsilon_{2}
\end{aligned}
$$

Dengan demikian diperoleh diagram jalur Model 2 (keseluruhan model) sebagai berikut

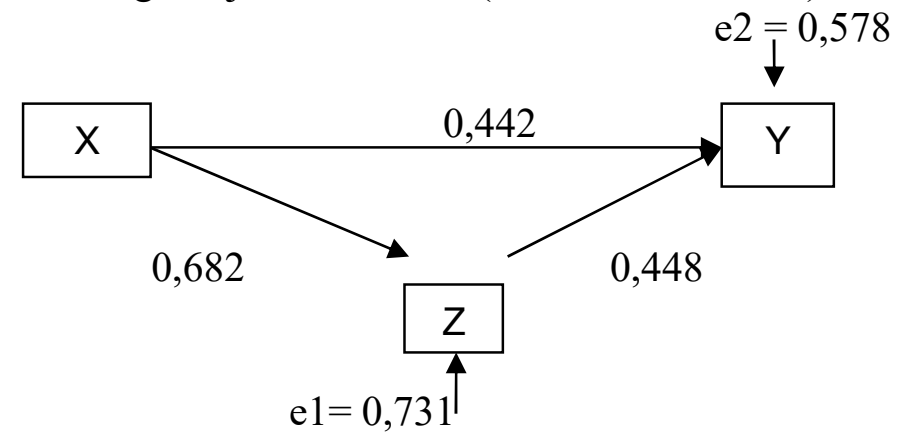

Besarnya koefisien Pengaruh tidak langsung $=0,682 \times 0,448=0,306$. Dengan demikian Total pengaruh adalah $=0,442+0,306=0,748$. Dengan demikian jika dibandingkan besarnya koefisien pengaruh langsung dan tidak langsung menunjukkan bahwa pengaruh religiusitas akan semakin besar jika melalui kepercayaan merek. Dengan demikian hipotesis yang menyatakan (H1) ; Terdapat pengaruh religiusitas terhadap perilaku 
konsumen dalam memilih bank syariah di kota Mataram diterima, dan (H2) Kepercayaan merek sebagai mediasi hubungan antara religiusitas dengan perilaku konsumen dalam memilih bank syariah di kota Mataram juga diterima.

\section{Pembahasan}

Religiusitas diwujudkan dalam berbagai sisi kehidupan termasuk aspek ekonomi. Pada zaman modern ini kegiatan perekonomian tidak akan sempurna tanpa adanya lembaga perbankan. Lembaga perbankan tersebut termasuk ke dalam aspek syariat yang berhubungan dengan kegiatan muamalah. Dalam kegiatan bermuamalah, perlu diperhatikan bahwa semua transaksi dibolehkan kecuali yang diharamkan oleh syariat, dan penyebab terlarangnya sebuah transaksi menurut syariat dikarenakan adanya faktor haram zatnya, haram selain zatnya, dan tidak sah.

Hasil penelitian ini membuktikan bahwa religiusitas menjadi variabel yang mempengaruhi keputusan nasabah dalam memilih perbankan syariah di Kota Mataram. Hasil ini memperkuat penelitian Mokhlis (2007 \& 2009) yang menunjukkan bahwa religiusitas harus dilibatkan sebagai penentu kemungkinan orientasi belanja dalam perilaku konsumen. Penelitian Haque, rahman \& Haque (2011) menegaskan bahwa niat beli dari konsumen merupakan bias persepsi konsumen yang bisa jadi muncul dari dorongan emosional yang muncul dari fanatisme agama. Hasil penelitian Lestari (2015), mengkaji secara langsung pengaruh religiusitas terhadap preferensi menabung mahasiswa, dan menemukan bahwa terdapat pengaruh signifikan. Hasil ini memperkuat dugaan bahwa bahwa agama dapat dilihat sebagai prediktor yang valid dalam penelitian konsumen dan disimpulkan bahwa ukuran multidimensional religiusitas merupakan pengukuran paling efisien dalam menjelaskan variasi dalm aspek perilaku konsumen.

Selain pengujian secara langsung, hasil ouput SPSS membuktikan pula bahwa religiusitas dapt mempengaruhi keputusan nasabah memilih perbankan syariah melalui variabel kepercayaan merek. Besarnya pengaruh tidak langsung ini menunjukkan koefisien yang lebih besar jika dibandingan dengan pengaruh langsung. Hal ini menunjukkan bahwa individu dengan tingkat religiusitas tertentu akan menentukan tingkat keyakinan, mempercayai dan dapat mengandalkan perbankan dengan merek tertentu, untuk bisa memenuhi harapan nasabah. Sebagai sebuah lembaga perbankan yang menggunakan istilah merek Syariah menjadi sebuah indikator yang menunjukkan bahwa dalam kegiatan operasional mereka bank syariah menjalankan kegiatannya sesuai dengan akidah, dapat dipercaya sebagai perbankan yang sesuai dengan syariat agama Islam dan tidak melakukan hal yang dapat menimbulkan sesuatu yang haram bagi nasabahnya, seperti bunga/ riba.

Semakin religius seseorang dalam segala aspek kehidupannya, semakin tinggi kepekaan mereka akan berbagai produk (barang dan jasa) yang sesuai dengan syariat agama. Produk dengan merek yang bisa menunjukkan ke syariah an atau ke halalan produk tersebut, akan dapat meningkatkan keyakinan mereka terhadap merek yang bersangkutan, dan pada akhirnya memungkinkan mereka berperilaku positif terhadap merek yang bersangkutan. Kepercayaan terhadap merek ini selanjutnya akan menjadi prediktor dalam mereka melakukan perilaku pembelian, terutama keputusan individu saat mereka memilih jasa perbankan.

Hasil penelitian yang membuktikan signifikansinya pengaruh tidak langsung ini, menunjukkan pula bahwa religiusitas yang dimiliki individu atau masyarakat umum, akan semakin bermakna ketika perbankan dapat menciptakan kepercayaan merek organisasi mereka. Adanya integritas yang tinggi (kejujuran pihak yang dipercaya dan kemampuan menempati janji), Benevolence (perhatian dan motivasi yang bertindak sesuai dengan kepentingan yang mempercayai mereka), Competency (kemampuan pihak yang dipercaya untuk melaksanakan kebutuhan yang mempercayai) dan predictability (konsistensi 
perilaku pihak yang dipercaya) menjadi hal penting dan tantangan kedepan bagi perbankan syariah. Sehingga meingkatkan dan memelihara kepercayaan tersebut dapat menjadi kunci keberhasilan perbankan syariah dalam kegiatannya di masa yang akan datang.

Hasil penelitian ini sejalan dengan temuan Alifianto (2014), meneliti tentang keputusan siswa untuk memilih pondok pesantren di propinsi Jawa Timur. Penelitian tersebut menunjukkan hasil adanya pengaruh antara religiusitas terhadapt keputusan siswa melalui kepercayan merek dari sekolah atau pondok pesantren yang memiliki merek sebagai lembaga pendidikan berbasis pendidikan agama Islam. Dengan demikian hasil penelitian ini memperkuat teori dan temuan empiris sebelumnya bahwa agama yang diukur dengan variabel Religiusitas dapat menjadi prediktor bagi perilaku konsumen dalam memilih sebuah produk.

\section{KESIMPULAN DAN SARAN}

Hasil penelitian ini membuktikan bahwa Religiusitas memiliki pengaruh positif dan signifikan baik secara langsung atau tidak langsung (melalui Kepercayaan Merek), terhadap perilaku nasabah dalam memutuskan memilih Perbankan Syariah di Kota Mataram. Hasil ini menunjukkan bahwa keyakinan, komitmen, dan sikap seseorang yang didasari nilai-nilai agama yang diyakini menjadi prediktor kuat, yang akan mengarahkan perilaku individu dalam melakukan pembelian/ menggunakan jasa. Pengunaan istilah merek tertentu yang menggambarkan karakteristik spesifik dari jasa yang akan diberikan menjadi hal yang penting dalam membentuk kepercayaan nasabah terhadap merek dan lembaga, serta dapat mempengaruhi keputusan nasabah.

Penelitian ini memberikan kontribusi bagi praktek dan penelitian teoritis, namun memiliki beberapa keterbatasan yang harus disadari, seperti : Para partisipan penelitian tidak seluruhnya hanya menjadi menjadi nasabah bank syariah, sehingga penelitian selanjutnya perlu dibedakan antara nasabah bank syariah saja, nasabah bank syariah dan konvensional. Penelitian ini adalah penelitian cross-sectional karena dilakukan pada satu titik waktu tertentu saja, penelitian selanjutnya yang bisa menggunakan disain penelitian longitudinal. Implikasi manajerial yang didapatkan dari penelitian ini, antara lain: (1) Pemasar perlu mempertimbangkan dan memperhatikan latar belakang agama target pasar yang di bidik,dan (2) Pemasar hendaknya dapat membuktikan makna merek yang melekat dalam organisasinya, sebagai penentu kepercayaan konsumen dalam memaknai merek.

\section{DAFTAR PUSTAKA}

Abhimantara, Maulanan, Agustianingsih, 2013, Analisis Faktor-faktor yang Mempengaruhi Nasabah (Mahasiswa) memilih Menabung Pada Bank Syariah, Proceeding PESAT, 5 Oktober, 2013, ISSN 1858-2559

Bank Indonesia.2014.Statistik Perbankan syariah.www.bi.go.id.

Chaudhuri, A., \& Holbrook, M. B. (2001). The Chain of Effects from Brand Trust and Brand Affect to Brand Performance: the Role of Brand Loyalty. Journal of Marketing, 65(April), 81-93.

Delener, N. (1994). Religious Contrast in Consumer Decision Behavior Patterns: Their Dimension and Marketing Implications. European Journal of Marketing, 28, 36-53. 
Departemen Keuangan. 2014. Cetak Biru Pengembangan Perbankan Syariah Indonesia.www.perpustakaan.depkeu.go.id.

Ferdinand Augusty,(2011), Metode Penelitian Mananajemen, Pedoman untuk Penulisan Skripsi, Tesis, dan Disertasi Ilmu Manajemen, Edisi 3, Seri Pustaka Kunci 10/2011, BP Undip, ISBN 979-704-254-5

Haque, A., Rahman, S., \& Haque, M. (2011). Religiousity, Ethnocentrism and Corporate Image Towards the Perception of Young Muslim Consumers: Structural Equation Modelling Approach. European Journal of Social Sciences, 23(1), 98-108.

Hawkins, D. I., Best, R. J., \& Coney, K. A. (2004). Consumer Behavior - Building Marketing Strategy. New York: McGraw-Hill.

Heri, H. (2011). Analisis Pengaruh Kualitas Pelayanan, Nilai Pelanggan, Kepuasan Pelanggan dan Citra Perusahaan Terhadap Kepercayaan Pelanggan (Studi Pada PDAM Provinsi Riau). Malang: Program Pasca Sarjana Universitas Brawijaya.

Karim, Adiwarman. 2011. Bank islam: Analisis Fiqih dan Keungan. Jakarta: Rajawali Press.

Khraim, H. (2010, November). Measuring Religiousity in Consumer Research from Islamic Perspective. International Journal of Marketing Studies, 2(2), 166-179.

Kim, S., David, S., \& Zafer, B. (2004). The Influence of Religion on Attitudes Towards the Advertising of Controversial Products. European Journal of Marketing, 38(5/6), 537-555.

Kotler, Phillip, (2003), Marketing Management, Eleventh Edition, International Edition, Prentice Hall

Lestari, Alfi Mulikhah, 2015, Pengaruh Religiusitas, Produk Bank, Kepercayaan, Pengetahuan, dan Pelayanan terhadap Preferensi menabung pada Perbankan Syariah (Studi Kasus Pada Mahasiswa FEB Universitas Brawijaya, Jurnal Ilmiah FEB Universitas Brawijaya

McCort, D., \& Malhotra, N. (1993). Culture and Consumer Behavior: Toward and Understanding of Cross-Cultural Consumer Behavior in International Marketing. Journal of International Consumer Marketing, 6(2), 91-127.

Mokhlis, S. (2007). Consumer Religiosity and Shopping Behavior in Kuala Lumpur. Malaysian Management Journal, 11(1), 87- 101.

Mokhlis, S. (2009, July). Relevancy and Measurement of Religiosity in Consumer Behavior Research. International Business Research, 2(3), 75-84. 
Rivai, Lukviarman, Syafrizal, Lukman, Andrianis, Masrizal, 2013, Identifikasi Faktor Penentu Keputusan Konsumen Dalam Memilih Jasa Perbankan: Bank Syariah vs Bank Konvensional

Saeed, M., Ahmed, Z., \& Mukhtar, S.-M. (2001). International Marketing Ethics from an Islamic Perspective: A Value-Maximization Approach. Journal of Business Ethics, 32, 127-142.

Santoso, Sinarasri, 2013, Analisis Religiusitas, Pemahaman Produk, dan Sistem Pembiayaan Syariah Dengan Sikap Pengusaha

Schiffman, Leon, Kanuk, (2007), Consumer Bahavior, $7^{\text {th }}$ Ed, Kasip, Zoelkifli (penerjemah), Perilaku Konsumen, Edisi Ketujuh, Indeks, Jakarta

Lau, G. T., \& Lee. (1999). Customer's Trust in a Brand and the Link to Brand Loyalty. Journal of Market Focused Management, IV,341-370. http://dx.doi.org/10.1023/A:1009886520142

Wilson, J. A., \& Liu, J. (2011). The Challenges of Islamic Branding: Navigating Emotions and Halal. Journal of Islamic Marketing, 2(1), 28-42. http://dx.doi.org/10.1108/17590831111115222 